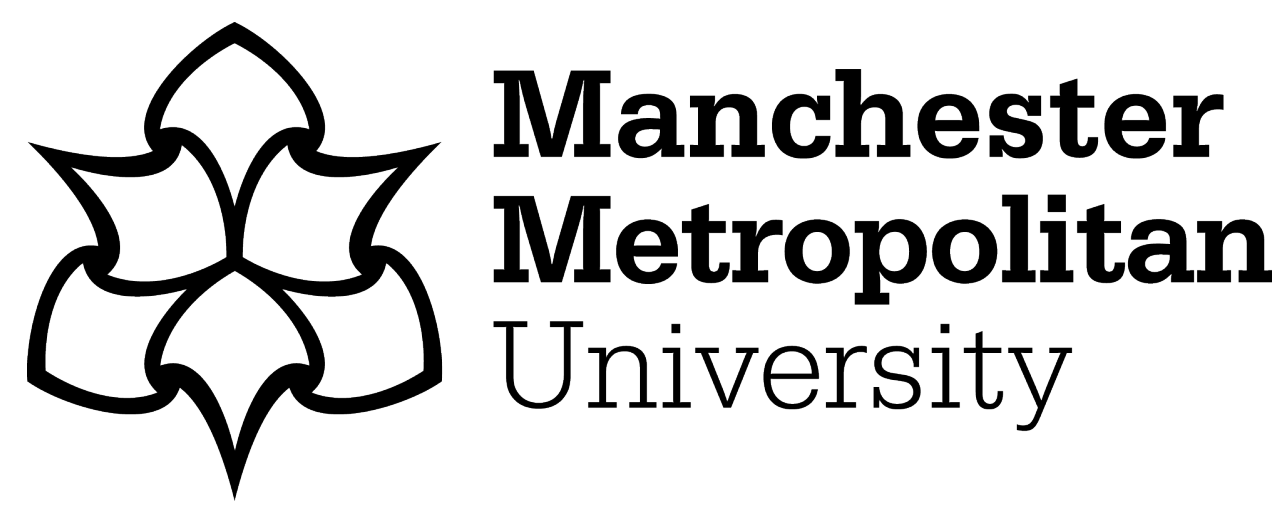

Collins, H, Allsopp, K, Arvanitis, K, Chitsabesan, P and French, P ORCID IogoORCID: https://orcid.org/0000-0003-4300-387X (2022) Psychological Impact of Spontaneous Memorials: A Narrative Review. Psychological Trauma: Theory, Research, Practice, and Policy, 14 (7). pp. 1230-1236. ISSN 19429681

Downloaded from: https://e-space.mmu.ac.uk/625623/

Publisher: American Psychological Association

DOI: https://doi.org/10.1037/tra0000565

Please cite the published version 


\section{Psychological Trauma: Theory, Research, Practice, and Policy}

\section{Psychological Impact of Spontaneous Memorials: A Narrative Review}

Hannah Collins, Kate Allsopp, Kostas Arvanitis, Prathiba Chitsabesan, and Paul French

Online First Publication, March 19, 2020. http://dx.doi.org/10.1037/tra0000565

\section{CITATION}

Collins, H., Allsopp, K., Arvanitis, K., Chitsabesan, P., \& French, P. (2020, March 19). Psychological Impact of Spontaneous Memorials: A Narrative Review. Psychological Trauma: Theory, Research, Practice, and Policy. Advance online publication.

http://dx.doi.org/10.1037/tra0000565 


\title{
Psychological Impact of Spontaneous Memorials: A Narrative Review
}

\author{
Hannah Collins \\ Pennine Care NHS Foundation Trust, Manchester, United \\ Kingdom, and Greater Manchester Mental Health NHS \\ Foundation Trust, Manchester, United Kingdom
}

Kostas Arvanitis

The University of Manchester

\author{
Kate Allsopp \\ Greater Manchester Mental Health NHS Foundation Trust, \\ Manchester, United Kingdom
}

\author{
Prathiba Chitsabesan and Paul French \\ Pennine Care NHS Foundation Trust, Manchester, United \\ Kingdom, and Manchester Metropolitan University
}

\begin{abstract}
Objective: The creation of spontaneous memorials has become an increasingly common response following a traumatic event, such as the Manchester Arena attack, the 2016 Paris attacks, and September 11, 2001, in New York. In many cases, spontaneous memorials are collected and archived. This article is the 1st to date to review the research literature on the potential psychological and therapeutic impact of such archives. Method: This study presents a literature review of 35 articles (including empirical research, discussion papers and gray literature) that explore the psychological functions of spontaneous memorials and why they may have been created. Results: Research has indicated that therapeutic impact is 1 of the main intended or assumed outcomes of such memorials and archives when it comes to those directly affected and the broader public. However, it has also been suggested that working with these materials can have a detrimental psychological impact on cultural professionals such as archivists, and research has recommended that mental health support should be in place for those working with the materials. This review indicates that there is limited research within this area and demonstrates a clear need to explore the impact of spontaneous memorials and their archives further, including avenues of support that may be helpful for professionals. Conclusion: Because spontaneous memorials are becoming an ever-increasing phenomenon, it is important to address this evidence gap to help guide cultural, health care, and other professionals in how best to present and potentially use these archives therapeutically in the future.
\end{abstract}

\section{Clinical Impact Statement}

The findings show that one of the main aims of memorials and archives created after traumatic events is to provide therapeutic value for the general public and those directly affected. Professionals such as archivists may be negatively affected by working with these distressing materials. Limited research in this area has been undertaken to date. It is important that this evidence gap be addressed with more empirical research. Our recommendations include (a) exploring the use of memorial archives as an adjunct to therapy as part of the trauma recovery process, (b) exploring potential negative impacts of spontaneous memorials, and (c) large-scale data collection.

Keywords: spontaneous memorials, psychological impact, therapeutic impact, terrorist attack, archives

Supplemental materials: http://dx.doi.org/10.1037/tra0000565.supp

"Spontaneous shrines" (Santino, 2016, p. 5) or "temporary memorials" (Doss, 2008, p. 6) are an increasingly common way of mourning by people and, more broadly, cities and communities that have been affected by a tragic event (Margry \& Sánchez-
Hannah Collins, Manchester Resilience Hub, Pennine Care NHS Foundation Trust, Manchester, United Kingdom, and Trafford Extended Service, Greater Manchester Mental Health NHS Foundation Trust, Manchester, United Kingdom; (D) Kate Allsopp, Complex Trauma and Resilience Research Unit, Greater Manchester Mental Health NHS Foundation Trust, Manchester, United Kingdom; (D Kostas Arvanitis, Institute for Cultural Practices, The University of Manchester; Prathiba Chitsabesan, Young People's Mental Health Research Unit, Pennine Care
NHS Foundation Trust, and Faculty of Health, Psychology \& Social Care, Manchester Metropolitan University; (D) Paul French, Pennine Care NHS Foundation Trust, Manchester, United Kingdom, and Faculty of Health Psychology and Social Care, Manchester Metropolitan University.

Correspondence concerning this article should be addressed to Hannah Collins, Greater Manchester Mental Health NHS Trust, Manor House Resource Centre, 5 Queen's Road, Urmston, Manchester M41 9HE, United Kingdom. E-mail: hannahcollins800@outlook.com 
Carretero, 2011; Santino, 2001, 2016). They emerge after events such as terrorist attacks, mass shootings, accidents, and natural disasters and are normally grassroots initiatives, involving survivors, bereaved families, and the broader public (Bazin, 2017). Although spontaneous memorials have been in evidence since the 1980s (Doss, 2010; Stengs, 2009), the death of Princess Diana (1997) brought the practice to wider public attention (Senie, 2006). Spontaneous memorials have now become a usual response to tragedies, such as the Manchester Arena attack on May, 22, 2017, where flowers and over 10,000 other objects, including personal mementos, candles, balloons, and written messages, were left. This is similar to the case for tragedies in other cities, such as the Madrid train bombings in 2004 (Sánchez-Carretero, Cea, DíazMas, Martínez, \& Ortiz, 2011), the September 11, 2001 (9/11), terrorist attack in New York City (Grider, 2001), the 1995 Oklahoma City bombing (Jorgensen-Earp \& Lanzilotti, 1998), the Norway attacks in 2011 (Lödén, 2014), and the Brussels attacks in 2016 (Milošević, 2018).

Because spontaneous memorials are temporary, due to the nature of their contents (e.g., flowers, paper messages; Santino, 1986), decisions are made to dismantle and collect memorial items, due to the weather (Grider, 2001) and security concerns and a decrease in media attention (Milošević, 2018). The collection and preservation of spontaneous memorials demonstrates their emotional value to many people (Farber, 2005). Cultural professionals are often tasked with the conservation, storage, and documentation of the collected items. In Oklahoma, after the 1995 bombing, archivists incorporated items into a permanent memorial (Doss, 2002; Senie, 2013). In other cities, including Paris concerning the attacks in 2015 (Paris Archives, n.d.), photographs have been taken to create an online archive, and plans are in place for a related project after the Manchester Arena attack. Following the 9/11 terrorist attack, items were offered to museums across the city (Lisle, 2004).

In short, spontaneous memorials and their archives now appear to be an expected response to a disaster rather than an exception (Milošević, 2018). It is said to be one of the ways society copes with and processes a traumatic event (Santino, 2011). Taking part in collective memorializing after a traumatic event has been argued to be helpful for both individual and community recovery (Whitton, 2016). Memorials are often presented as a key therapeutic step in the grieving process by providing a safe space for individuals and communities to grieve Rosenblatt (1997). Archives of spontaneous memorials often aim to have a therapeutic value for survivors, bereaved families, and the broader public (Jesiek \& Hunsinger, 2008; Micieli-Voutsinas, 2017; Recuber, 2012). Eyre (1999) suggested that not having these spaces can hinder recovery, because people do not have the opportunity to reestablish control, belonging, and social solidarity, which is believed to occur following collective expression. To date, however, this research has been limited and has not yet been reviewed. There is a larger body of empirical research on the psychological impacts of permanent memorials compared to spontaneous memorials. Savage (2009) suggested that permanent memorials such as the main Vietnam Veterans Memorial (VVM) in Washington have purposively been created with the intention of offering a therapeutic value for veterans and the public. Watkins, Cole, and Weidemann (2010) investigated these potential therapeutic impacts of the VVM for a group of Vietnam military veterans. It was concluded that there may be a therapeutic benefit to conducting regular trips to improve symptoms of posttraumatic stress disorder (PTSD).

In light of this research, this article had two main aims: First, it reviews literature that specifically addresses the link between spontaneous memorials and their archives with potential positive psychological impact. Second, the article discusses literature on the psychological impact of the process of archiving spontaneous memorials on cultural professionals, volunteers, visitors, and people affected by the events that they memorialize.

\section{Method}

Several literature searches were conducted to identify the literature on the psychological impact of spontaneous memorials. Research articles were identified by conducting electronic database searches on Scopus, PsycINFO, PubMed, and Science Direct using a combination of search terms, including memorialization, grassroot memorials, spontaneous shrine, spontaneous memorial, temporary memorial, shrine, grief materials, trauma, mass casualty, terrorist attack, incident, attack, suicide, grief, ghost bike, car crash, accident, roadside memorial, archivist, cultural professionals, collector, and curator. A manual search of the reference lists of included articles was carried out. The initial search focused on articles that looked at the psychological impact of memorials following a traumatic event. Due to limited literature on the search topic, the search was broadened to include all articles that discussed the psychological functions of spontaneous, public, physical memorials, and archives, as well as articles that described why spontaneous memorials may have been created. This included research articles that directly explored these areas and discussion papers and gray literature, including guidelines or recommendations and online articles or websites. The review excluded articles on permanent memorials and online memorialization. The searches were not limited by date; the earliest included article that was found was from 1997. With the exception of gray literature, articles were required to be in the English language. The searches yielded 519 unique articles; 35 articles were included in the review.

\section{Results}

Table 1 in the online supplemental materials summarizes the 35 studies selected. As shown, the methodology of the studies ranged from using qualitative designs and mixed methods, which typically included interviews, unobtrusive observations, and visual and content analysis of materials. Nine of the articles were narrative summaries that did not report a methodological design, two were literature reviews, and two were personal accounts. Of the 22 studies that carried out research with participants, only eight reported a sample size, the group of participants they included, and the methodology used. Participants from the studies included bereaved family members (four studies), visitors or creators of spontaneous memorials (seven studies), cultural professionals (four studies), and authority employees (one study). Much of the research carried on spontaneous memorials has focused on memorials created following a terrorist attack; the studies included 14 different international terrorist attacks, and six of the studies focused on more general or individualized spontaneous memorials. 


\section{Positive Psychological Impacts of Spontaneous Memorials}

This section is further divided into three themes that have been highlighted in the literature: individual processing of grief, strengthening a sense of community, and confronting the site of the incident.

Individual processing of grief. Permanent memorials and spontaneous memorials have been described as a "device to manage emotions and deal with grievances and contestation" (Margry \& Sánchez-Carretero, 2011, p. 24). Bereaved parents have found them important, whether it be planting a special garden, lighting candles, or going to a certain memory spot (Maple, Edwards, Minichiello, \& Plummer, 2013). Maple and colleagues (2013) found that benefits included feeling connected to loved ones, keeping the memory of them alive, and making sure they remain part of the family. Interviews carried out by Klaassens, Groote, and Huigen (2009) found similar motivations for bereaved families and friends when creating a roadside memorial.

In Western societies, spontaneous memorialization has become increasingly common following both major incidents or disasters and individual losses, such as roadside accidents (Howarth, 2007). Doss (2008) argued that spontaneous memorials have the capacity to offer a mechanism that allows individuals to understand and process a traumatic death, because they are rich with meaning and hold emotional and symbolic power. Interviews carried out by Petersson (2009) also found benefits, including the spontaneous memorial providing structure and meaning for the bereaved families' or friends' existence.

Researchers have explored the shift to spontaneous memorialization as an American mourning ritual (Haney, Leimer, \& Lowery, 1997). Haney and colleagues (1997) believed spontaneous memorials allow participants to fulfill their emotional needs that are no longer being met by contemporary U.S. death rituals. For example, they argued that spontaneous memorialization provides a space where people can express "anger, revenge and guilt" (emotions that are often part of the bereavement process; p. 163) and a method for grieving "personal, social and cultural losses" (p. 162). They also described how spontaneous memorials help to reduce threat to basic human needs by promoting values such as safety and justice by a large community.

Strengthening a sense of community. Moodley and Costa (2006) argued that memorials allow individuals to experience closure and form a sense of belonging to a community. They have been conceptualized as a manifestation of a sense of community, in the aftermath of an event (Milošević, 2017). Senie (2006) argued that spontaneous memorials have "worked to heal, bringing people together in grief" (p. 47). Through analysis of memorial messages left following the Norway attacks in 2011, Døving (2018) found that many expressed how good it felt to visit the spontaneous memorials and "feel like part of the community" (p. 241). Similarly, Casey (2007), who visited a 9/11 spontaneous memorial in Union Square Park, described the visit as

a sense of relief to find oneself in the presence of others-albeit strangers-with whom to share one's chagrin and grief. There was a palpable sense of coming to terms with a trauma instead of letting oneself be crushed by it. (p. 76)
Following the 2013 Boston Marathon bombings, Beinecke et al. (2017) found the role of "perfect strangers" (p. 103) was vital for building resilience and healing because it offered a sense of togetherness and loyalty. Kverndokk (2013) argued that spontaneous memorials offer space and opportunity for this to occur. Milošević (2018) suggested this could be "a sort of a sympathetic hug of a society of strangers" and "the therapeutic purpose of memorials and remembrance should not be taken for granted" ( $p$. 63). Research does not clearly and specifically define and assess the nature, boundaries, manifestations, and effects of this therapeutic impact. The discourse used seems to equate therapeutic impact with arguments about solidarity, resilience, and social cohesion.

These meanings are reflected in the ways that trauma is conceptualized within archives and collections of spontaneous memorials; for example, Rivard (2012) argued that at the September 11 Collection at Smithsonian's National Museum of American History viewers were guided to feel an emotional connection with objects as representations of the loss of life. Comparable claims have been made about the link between archives in museums, libraries, or related cultural organizations and their possible therapeutic impact on people, although evidence is limited. This narrative is often framed around the (self-)perception of museums as places of civic healing (Gardner \& Henry, 2002). Accordingly, materials from such memorials are often archived because "it is seen as the solidified emotion of trauma" (Margry \& SánchezCarretero, 2011, p. 16).

Taking back or confronting the site of an incident. Through interviews with bereaved families following roadside accidents, Klaassens, Groote, and Vanclay (2013) found that spontaneous memorials at the site of the accident played an important role in the bereavement process. During a stressful time filled with overwhelming emotion, the creation of a spontaneous memorial gave people pleasure as well as taking away the horror from the traumatic site of death, turning it into a place of care and nurture. Similarly, the creator of a "ghost bike" (a roadside memorial, with a white painted bicycle placed where a cyclist has been killed) described the relief she felt following the discovery of ghost bikes, because it allowed her to do something positive "instead of just feeling like so depressed and upset about it all" (Dobler, 2011, p. 179). Dobler (2011) has therefore described the physical creation of a ghost bike as potentially therapeutic to mourners. Research has found that roadside memorials can be a way to grieve and cope with a traumatic death of a loved one, and creating a memorial may help to fill the gap left by their loss (Klaassens et al., 2009).

Yocom (2006), referring to the spontaneous memorial at the Pentagon, noted that "anything may happen at these roadside shrines: grieving might begin, healing may come ..." (p. 88). Dobler (2011), argued that participation in such memorials imparts "a sense of regained control in response to feelings of powerlessness in the face of unexpected traumatic death" (p. 178). Westgaard (2006), writing about spontaneous shrines for a young boy killed on a moped in a small village in Norway, stressed that "from a therapeutic point of view the spontaneous shrine as a ritual may be regarded as something that contributes to the 'correct' experience of grief" (p. 156).

Westgaard (2006), however, found people had varying reactions to the shrines. For some participants such shrines were "emotionally disturbing, exaggerated, and uncontrolled" (p. 165). To those 
ambivalent to the shrines, they were an opportunity to channel emotions. To people for whom they had positive value, "participating in the events at a spontaneous shrine is mental hygiene and it is healthy ... [and show] an appreciation of the therapeutic attributes of the shrine"; these attributes related to whether emotions were controlled (i.e., refrained from being expressed) or expressed freely (p. 168).

\section{The Impact and Challenges of Working With Spontaneous Memorials}

Collecting and archiving materials from spontaneous memorials is a complicated process, requiring local decisions around funding and long-term plans for storage (Grider, 2001). It can be psychologically demanding for those involved (Maynor, 2016; Morin, 2015; Schwartz, Broadaway, Arnold, Ware, \& Domingo, 2018; Whitton, 2016, 2017). Schwartz and colleagues (2018) described their personal experiences of collecting material from spontaneous memorials and creating exhibitions at the Orange County Regional History Center in Orlando, Florida, after the 2016 Pulse Nightclub massacre there. They described their job as physically and emotionally demanding, requiring very long days, and "only in the privacy of our own homes, held by our loved ones, could we truly break down and release the tears we had been holding in" (p. 112). When the tragic events associated with the Orlando memorials had particular personal resonance for cultural professionals, they found it difficult to process and described not having the emotional strength to take part in certain aspects of the archiving, such as collecting from the site of the incident itself. During the process of clearing the memorial in Paris, archivists tried not to read the written messages. As the director of the Paris Archives said, "We went to the field as doctors to protect ourselves from emotional reactions that were too strong. Of course, some documents have marked us, especially those of foreign communities living in Paris, or foreigners passing through" (Benhaiem, 2016, para 15).

This is consistent with findings by Maynor (2016), who interviewed people involved in managing the response to three mass casualty incidents (the 1999 Texas A\&M University bonfire tragedy, the 2007 Virginia Tech campus shooting, and the 2012 Sandy Hook school shooting). All interviewees from the three case studies commented on the emotional burden of their role, with one individual describing the role of an archivist like "working in a wake" (Maynor, 2016, p. 617). The psychological impact of working with the spontaneous memorial material over a sustained period without preparation for its emotional burden was compared to a soldier going to war with no training (Maynor, 2016). Similarly, a curator of the 9/11 incident highlighted that long conversations with participants and donors

often included a lot of crying — us included. It is difficult dealing with death and frankly none of us were prepared for the task. At times each one of us was ready to throw in the towel but the support and pressure of the others kept us going. (Liebhold, 2011, para. 10)

Best practices for professionals involved in the management and aftermath of spontaneous memorials highlight the impact on individuals undertaking the archiving (Maynor, 2016; Morin, 2015; Whitton, 2016, 2017). Maynor (2016) and Morin (2015) recommended those involved seek support from colleagues, mental health professionals, and/or supportive communities if required.
These studies suggest the emotional burden of cultural professionals is taken into account during the archiving process. Doss (2010) warned that reports on the benefits of generic grief counseling are speculative, which raises further the question of appropriately designed and targeted support.

Despite the challenging aspects of collecting and documenting spontaneous memorials, this experience is far from negative. On the contrary, as argued by Arvanitis (2019), in the case of the Manchester Arena attack, the formation of the Manchester Together Archive was a creative process of negotiating the interaction between professional ethics and a strong sense of civic and social responsibility. Furthermore, Arvanitis (2020) examined how the tactile acts of handling the soft toys became part of people's personal and collective process of overcoming the trauma of the Manchester Arena attack. Arvanitis (2020) argued that cleaning the soft toys channeled people's need to contribute to and participate in a shared expression of solidarity to the city and its recovery, though their temporary effects have also been highlighted (Steinert, 2003). Sanford (2018), a museum registrar, through conversations with visitors and creators of the memorials following the 2017 Las Vegas shooting, described how she learned the value and emotional importance for the community of spontaneous memorials, because it allowed people to fulfill their need of wanting to do something in a time of need. Likewise, Schwartz and colleagues (2018) described that 1 year on, they were able to witness the therapeutic impact of their work and observe friends and family members gaining comfort from the displayed memorial items.

\section{Discussion}

Spontaneous memorials are an increasingly common phenomenon following tragic events (Santino, 2016). This review summarized 35 included studies that discussed their purpose and psychological impact. The discussion here outlines the main themes drawn from the review, highlighting limitations in the research. Practice and research implications are then discussed.

Much of the narrative around the role and value of spontaneous memorials is based on their perceived healing and therapeutic impact for survivors, bereaved families, and other members of the local or broader community. Individual processing of grief, strengthening a sense of community, and confronting the site of the incident were found to be the general themes that people identified as being positive psychological impacts of the memorials. Although some research suggested a potential therapeutic or positive impact, the research is limited and lacks rigorous methodological designs. Furthermore, the majority of the identified studies employed cross-sectional designs; from this research, therefore, it cannot be known whether viewing or producing such memorials has a lasting impact on the process of recovery from trauma. It is notable that none of the literature explored the potential negative impact of nonprofessionals engaging with spontaneous memorials. For example, Watkins and colleagues (2010) found that for veterans visiting a permanent Vietnam War memorial, although some had a beneficial therapeutic response, the number of times they visited the memorial was important, because others had an increase in posttraumatic symptoms after viewing the memorial only once.

The second overarching theme of the review highlights the psychological or demanding impact on cultural professionals who 
archive memorial material following a major incident. The literature identifies the emotional and physical demands and the recommendations of the support that professionals should receive while carrying out this work (Maynor, 2016; Morin, 2015; Schwartz et al., 2018; Whitton, 2016, 2017). This literature is consistent with research from other professions and types of trauma, where studies have shown that vicarious or indirect trauma can take the same role or experience for the victim as direct trauma does (Brewin, Andrews, \& Valentine, 2000; Carlier, Lamberts, \& Gersons, 2000; Eriksson, Vande Kemp, Gorsuch, Hoke, \& Foy, 2001). Work-related or secondary traumatization has been found to be prominent in many other professions, such as for mental health professionals (Finklestein, Stein, Greene, Bronstein, \& Solomon, 2015), medical examiner personnel (Coleman, Delahanty, Schwartz, Murani, \& Brondolo, 2016), and exposed disaster and rescue workers (Fullerton, Ursano, \& Wang, 2004).

\section{Practice Implications for Professionals}

It is clear, therefore, that psychological support needs to be in place for cultural professionals and volunteers. Training for supervisors and peers to provide immediate and targeted support may be beneficial (Scott \& colleagues, 2009). The support offered to professionals involved in archiving materials after the Manchester Arena attack (Arvanitis, 2019) provide an example for practitioners involved in future incidents to help overcome the negative effects highlighted by this review.

Following the Manchester Arena attack (2017), members of the archiving team met with clinical staff at the Manchester Resilience Hub (a service set up to support people with mental health-related problems following the arena incident; French et al., 2019). Group meetings offered staff guidance and support on how to process their emotions and look after their well-being during the archiving process. The meetings allowed team members to share and process their feelings, which normalized their responses to the material and enabled them to realize they were shared by others, which has been said to be beneficial and has been discussed in detail in relevant literature (McLeod, 1997; Pennebaker, 1997). It also allowed the team to better understand the psychological state, emotional needs, and expectations of the bereaved families that visited the archive (Arvanitis, 2019). However, although training and support for cultural professionals has been recommended, and utilized, the approaches have not yet been formally evaluated.

\section{Research Implications}

Spontaneous memorials and their archives offer a space for people to grieve and may add an additional dimension to the recovery process. However, only eight of the included articles reported a sample size, the group of participants they included, and the methodology used, all of which could usefully be included in reporting standards for future studies. Although discussion papers highlighted compelling ideas about the positive psychological impacts of spontaneous memorials, these require empirical testing. Further research is therefore required to understand the multiple impacts associated with such memorials (Sánchez-Carretero, 2011). To counter the limitations highlighted in the current research literature, key areas for further research and associated methodologies are recommended below; these encompass the following: large-scale data collection, under- standing the potential negative impact of spontaneous memorials, and therapeutic uses of memorials in the process of recovery.

Large-scale data collection could be used to gather wider community views on engagement spontaneous memorials; for example, epidemiological research and programs that frequently follow mass casualty incidents could ask qualitative and quantitative questions regarding participation with spontaneous memorials. In addition, longitudinal design and collection of data at different time points could be utilized to understand whether there is an optimum time for people to engage with spontaneous memorials, or whether the timing varies between individuals depending on their experiences, and why. For example, Páez, Basabe, Ubillos, and González-Castro (2007) used large-scale questionnaire data from 661 college students and their relatives in Spain at different time points shortly after the attack to examine how taking part in rituals following the Madrid train attacks of 2004 helped fulfill some psychosocial functions.

Notable gaps in the literature were around understanding the potential negative impact of spontaneous memorials for nonprofessionals and the potential use of these memorials in the process of recovery. Existing research should be expanded upon by using more rigorous qualitative methodological designs, including purposive sampling to actively seek out the perspectives of people who may have found that memorials were not beneficial, or even harmful (e.g., triggering of mental distress including PTSD), and under what circumstances. To evaluate the therapeutic uses of memorials in the process of recovery, researchers should use feasibility studies and randomized control trials to understand whether engagement with memorial archives could be a useful adjunct to therapy and should monitor any detrimental effects on mental health that may arise. Different groups (e.g., survivors compared with bereaved families) as well as different formats (e.g., physical or digital memorial archives such as those in Paris; Paris Archives, n.d.) should be compared to make recommendations about who may benefit most from such an intervention and as part of self-help or formal therapy. Qualitative studies should further explore participants' perspectives on the acceptability and utility of engaging with memorials as part of therapy.

\section{Conclusion}

The creation of spontaneous memorials is an increasingly common response to tragic events (Santino, 2016). The research included in this review suggests that engaging with or producing such memorials may have a positive psychological impact for survivors, bereaved families, and members of the community. Conversely, working with memorial materials, such as through archiving processes, is physically and emotionally demanding, and training and support for professionals is necessary. However, the psychological research in this area is in its infancy, and this review highlights the need for more rigorous empirical research, and there are important areas that require further exploration. Nevertheless, engagement with spontaneous memorials may represent a promising avenue for exploration as a therapeutic tool in the process of recovery from trauma.

\section{References}

Arvanitis, K. (2019). The "Manchester Together Archive": Researching and developing a museum practice of spontaneous memorials. Museum \& Society, 17, 510-532. http://dx.doi.org/10.29311/mas.v17i3.3203

Arvanitis, K. (2020). 2,000 soft toys: Washing trauma of(f) memory. Manuscript in preparation. 
Bazin, M. (2017, May 26). Quand la rue prend le deuil: Les mémoriaux éphémères après les attentats [When the street mourns: Ephemeral memorials after the attacks]. Retrieved from https://www.laviedesidees .fr/Quand-la-rue-prend-le-deuil.html

Beinecke, R., Raymond, A., Cisse, M., Renna, K., Khan, S., Fuller, A., \& Crawford, K. (2017). The mental health response to the Boston bombing: A three-year review. International Journal of Mental Health, 46, 89-124. http://dx.doi.org/10.1080/00207411.2017.1294969

Benhaiem, A. (2016, September). Boîte à tristesse et fleurs en papier ... les Archives de Paris exposent les hommages des attentats pour les Journées du patrimoine [Box of sadness and paper flowers ... the Archives of Paris expose the tributes of the attacks for Heritage Days]. Retrieved from https://www.huffingtonpost.fr/2016/09/16/attentatsnovembre-archives-paris-journees-patrimoine_n_11993524.html

Brewin, C. R., Andrews, B., \& Valentine, J. D. (2000). Meta-analysis of risk factors for posttraumatic stress disorder in trauma-exposed adults. Journal of Consulting and Clinical Psychology, 68, 748-766. http://dx .doi.org/10.1037/0022-006X.68.5.748

Carlier, I. V., Lamberts, R. D., \& Gersons, B. P. (2000). The dimensionality of trauma: A multidimensional scaling comparison of police officers with and without posttraumatic stress disorder. Psychiatry Research, 97, 29-39. http://dx.doi.org/10.1016/S0165-1781(00)00211-0

Casey, E. S. (2007). Public memory in the making: ethics and place in the wake of 9/11. In G. Caicco (Ed.), Architecture, ethics, and the personhood of place (pp. 69-90). Hanover, NH: University Press of New England.

Coleman, J. A., Delahanty, D. L., Schwartz, J., Murani, K., \& Brondolo, E. (2016). The moderating impact of interacting with distressed families of decedents on trauma exposure in medical examiner personnel. Psychological Trauma: Theory, Research, Practice, and Policy, 8, 668-675. http://dx.doi.org/10.1037/tra0000097

Dobler, R. T. (2011). Ghost bikes: Memorialization and protest on city streets. In P. Margry \& C. Sánchez-Carretero (Eds.), Grassroots memorials: The politics of memorializing traumatic death (pp. 169-187). New York, NY: Berghahn Books.

Doss, E. (2002). Death, art and memory in the public sphere: The visual and material culture of grief in contemporary America. Mortality, 7, 63-82. http://dx.doi.org/10.1080/13576270120102553

Doss, E. (2008). Emotional life of contemporary public memorials towards a theory of temporary memorials. http://dx.doi.org/10.5117/ 9789089640185

Doss, E. L. (2010). Memorial mania: Public feeling in America. http://dx .doi.org/10.7208/chicago/9780226159393.001.0001

Døving, A. C. (2018). Homeland ritualised: An analysis of written messages placed at temporary memorials after the terrorist attacks on 22 July 2011 in Norway. Mortality, 23, 231-246. http://dx.doi.org/10.1080/ 13576275.2017.1346597

Eriksson, C., Vande Kemp, H., Gorsuch, R., Hoke, S., \& Foy, D. (2001). Trauma exposure and PTSD symptoms in international relief and development personnel. Journal of Traumatic Stress, 14, 205-212. http:// dx.doi.org/10.1023/A:1007804119319

Eyre, A. (1999). In remembrance: Post disaster rituals and symbols. Australian Journal of Emergency Management, 14, 23-29.

Farber, L. A. (2005). Issues in the collection and conservation of American vernacular memorial art. In S. Zachary (Ed.), The book and paper group annual (Vol. 24, pp. 5-16). Washington, DC: Book and Paper Group, American Institute for Conservation of Historic and Artistic Works.

Finklestein, I., Stein, E., Greene, T., Bronstein, I., \& Solomon, Z. (2015). Posttraumatic stress disorder and vicarious trauma in mental health professionals. Health \& Social Work, 40, e25-e31. http://dx.doi.org/10 $.1093 / \mathrm{hsw} / \mathrm{hlv026}$

French, P., Barrett, A., Allsopp, K., Williams, R., Brewin, C. R., Hind, D., ... Chitsabesan, P. (2019). Psychological screening of adults and young people following the Manchester Arena incident. BJPsych Open, 5(5): e85. http://dx.doi.org/10.1192/bjo.2019.61

Fullerton, C. S., Ursano, R. J., \& Wang, L. (2004). Acute stress disorder, posttraumatic stress disorder, and depression in disaster or rescue workers. American Journal of Psychiatry, 161, 1370-1376. http://dx.doi.org/ 10.1176/appi.ajp.161.8.1370

Gardner, J. B., \& Henry, S. M. (2002). September 11 and the mourning after: Reflections on collecting and interpreting the history of tragedy. Public Historian, 24, 37-52. http://dx.doi.org/10.1525/tph.2002.24.3.37

Grider, S. (2001). Spontaneous shrines: A modern response to tragedy and disaster. New Directions in Folklore, 5, 1-10. Retrieved from https:// scholarworks.iu.edu/journals-playground/index.php/ndif/article/view/ $19882 / 25952$

Haney, C. A., Leimer, C., \& Lowery, J. (1997). Spontaneous memorialization: Violent death and emerging mourning ritual. Omega: Journal of Death and Dying, 35, 159-171. http://dx.doi.org/10.2190/7U8W-540LQWX9-1VL6

Howarth, G. (2007). Death \& dying: A sociological introduction. Cambridge, United Kingdom: Polity Press.

Jesiek, B., \& Hunsinger, J. (2008). The April 16 archive: Collecting and preserving the memories of the Virginia Tech tragedy. In B. Agger \& T. W. Luke (Eds.), There is a gunman on campus: Tragedy and terror at Virginia Tech (pp. 29-54). New York, NY: Rowman \& Littlefield.

Jorgensen-Earp, C., \& Lanzilotti, L. A. (1998). Public memory and private grief: The construction of shrines at the sites of public tragedy. Quarterly Journal of Speech, 84, 150-170. http://dx.doi.org/10.1080/0033563 9809384211

Klaassens, M., Groote, P., \& Huigen, P. P. (2009). Roadside memorials from a geographical perspective. Mortality, 14, 187-201. http://dx.doi .org/10.1080/13576270902808068

Klaassens, M., Groote, P. D., \& Vanclay, F. M. (2013). Expressions of private mourning in public space: The evolving structure of spontaneous and permanent roadside memorials in The Netherlands. Death Studies, 37, 145-171. http://dx.doi.org/10.1080/07481187.2011.641137

Kverndokk, K. (2013). Negotiating terror, negotiating love: commemorative convergence in Norway after the terrorist attack on 22 July 2011. In C. A. Ingemark (Ed.), Therapeutic uses of storytelling: An interdisciplinary approach to narration as therapy (pp. 133-158). Lund, Sweden: Nordic Academic Press.

Liebhold, P. (2011, August 3). Collecting September 11: One curator's story. Retrieved from http://americanhistory.si.edu/blog/2011/08/ collecting-september-11-one-curators-story.html

Lisle, D. (2004). Gazing at Ground Zero: Tourism, voyeurism and spectacle. Journal for Cultural Research, 8, 3-21. http://dx.doi.org/10.1080/ 1479758042000797015

Lödén, H. (2014). Peace, love, depoliticisation and the domestic alien: National identity in the memorial messages collected after the terror attacks in Norway 22 July 2011. National Identities, 16, 157-176. http://dx.doi.org/10.1080/14608944.2014.918593

Maple, M., Edwards, H. E., Minichiello, V., \& Plummer, D. (2013). Still part of the family: The importance of physical, emotional and spiritual memorial places and spaces for parents bereaved through the suicide death of their son or daughter. Mortality, 18, 54-71. http://dx.doi.org/ 10.1080/13576275.2012.755158

Margry, P., \& Sánchez-Carretero, C. (2011). Rethinking memorialization: The concept of grassroots memorials. In P. Margry, \& C. SánchezCarretero (Eds.), Grassroots memorials: The politics of memorializing traumatic death (pp. 1-48). Oxford, United Kingdom: Berghahn Books. Maynor, A. R. (2016). "Response to the unthinkable: Collecting and archiving condolence and temporary memorial materials following public tragedies”. In E. M. Decker \& J. A. Townes (Eds.), Handbook of research on disaster management and contingency planning in modern libraries (pp. 582-624). Hershey, PA: Information Science Reference. 
McLeod, J. (1997). Narrative and psychotherapy. http://dx.doi.org/10 $.4135 / 9781849209489$

Micieli-Voutsinas, J. (2017). An absent presence: Affective heritage at the National September 11th Memorial \& Museum. Emotion, Space and Society, 24, 93-104. http://dx.doi.org/10.1016/j.emospa.2016.09.005

Milošević, A. (2017). Remembering the present: Dealing with the memories of terrorism in Europe. Journal of Terrorism Research, 8, 44-61. http://dx.doi.org/10.15664/jtr.1269

Milošević, A. (2018). Historicizing the present: Brussels attacks and heritagization of spontaneous memorials. International Journal of Heritage Studies, 24, 53-65. http://dx.doi.org/10.1080/13527258.2017.1362574

Moodley, R., \& Costa, I. (2006). Teddy bears, flowers and crucifixes: Collective responses to trauma. International Journal of Health Promotion and Education, 44, 38-42. http://dx.doi.org/10.1080/14635240 .2006 .10708064

Morin, S. A. (2015). A museum's reference guide to collecting spontaneous memorials. Retrieved from https://www.nemanet.org/files/6414/3931/ 6844/S_Morin_reference_Guide.pdf

Páez, D., Basabe, N., Ubillos, S., \& González-Castro, J. L. (2007). Social sharing, participation in demonstrations, emotional climate, and coping with collective violence after the March 11th Madrid bombings. Journal of Social Issues, 63, 323-337. http://dx.doi.org/10.1111/j.1540-4560 .2007.00511.x

Paris Archives. (n.d.). Hommages numérisés [Digital Tributes]. Retrieved from http://archives.paris.fr/f/hommages/mosaique/

Pennebaker, J. W. (1997). Opening up: The healing power of expressing emotions. New York, NY: Guilford Press.

Petersson, A. (2009). Swedish offerkast and recent roadside memorials. Folklore, 120, 75-91. http://dx.doi.org/10.1080/00155870802647841

Recuber, T. (2012). The prosumption of commemoration: Disasters, digital memory banks, and online collective memory. American Behavioral Scientist, 56, 531-549. http://dx.doi.org/10.1177/0002764211429364

Rivard, C. (2012). Collection disaster: National identity and the Smithsonian's September 11 collection. Australasian Journal of American Studies, 31, 87-102.

Rosenblatt, P. (1997). Grief in small-scale societies. In P. C. Murray, L. Pittu, \& B. Young (Eds.), Death and bereavement across culture. London, UK: Routledge.

Sánchez-Carretero, C. (2011). The Madrid train bombings: Enacting the emotional body at the March 11 grassroots memorials. In P. Margry \& C. Sánchez-Carretero (Eds.), Grassroots memorials: The politics of memorializing traumatic death (pp. 244-261). New York, NY: Berghahn Books.

Sánchez-Carretero, C., Cea, A., Díaz-Mas, P., Martínez, P., \& Ortiz, C. (2011). On blurred borders and interdisciplinary research teams: The case of the "archive of mourning." Forum Qualitative Sozialforschung, 12(3): 12. Retrieved from http://nbn-resolving.de/urn:nbn:de:0114fqs 1103124

Sanford, C. (2018, October 2). Preserving grief: What to do with spontaneous memorials [Video file]. Retrieved from https://www.youtube $. c o m /$ watch? $\mathrm{v}=$ _eI9FDBDm6Y

Santino, J. (1986). The folk assemblage of autumn: Tradition and creativity in Halloween folk art. In J. M. Vlach \& S. J. Bronner (Eds.), Folk art and art worlds (pp. 151-169). Ann Arbor: University of Michigan Research Press.

Santino, J. (2001). Signs of war and peace: social conflict and the use of public symbols in Northern Ireland (1st ed.). http://dx.doi.org/10.1007/ 978-1-4039-8233-9

Santino, J. (2016). Performative commemoratives: Spontaneous shrines and the public memorialization of death. In J. Santino (Ed.), Spontaneous shrines and the public memorialization of death (pp. 5-15). http:// dx.doi.org/10.1007/978-1-137-12021-2_2

Santino, J. (2011). Between commemoration and social activism: Spontaneous shrines, grassroots memorialization, and the public ritualesque. In P. Margry \& C. Sánchez-Carretero (Eds.), Grassroots memorials: The politics of memorializing traumatic death (pp. 96-107). New York, NY: Berghahn Books.

Savage, K. (2009). Monument wars: Washington, DC, the National Mall, and the transformation of the memorial landscape. Berkeley: University of California Press.

Schwartz, P., Broadaway, W., Arnold, E. S., Ware, A. M., \& Domingo, J. (2018). Rapid-response collecting after the Pulse nightclub massacre. Public Historian, 40, 105-114. http://dx.doi.org/10.1525/tph.2018.40.1 .105

Scott, S. D., Hirschinger, L. E., Cox, K. R., McCoig, M., Brandt, J., \& Hall, L. W. (2009). The natural history of recovery for the healthcare provider "second victim" after adverse patient events. BMJ Quality \& Safety, 18, 325-330. http://dx.doi.org/10.1136/qshc.2009.032870

Senie, H. F. (2006). Mourning in protest: Spontaneous memorials and the sacralization of public space. In J. Santino (Ed.), Spontaneous shrines and the public memorialization of death (pp. 41-56). http://dx.doi.org/ 10.1007/978-1-137-12021-2_4

Senie, H. F. (2013). Commemorating the Oklahoma City bombing: Reframing tragedy as triumph. Public Art Dialogue, 3, 80-109. http://dx .doi.org/10.1080/21502552.2013.766870

Steinert, H. (2003). Unspeakable September 11th: Taken for-granted assumptions, selective reality construction and populist politics. International Journal of Urban and Regional Research, 27, 651-665. http://dx .doi.org/10.1111/1468-2427.00472

Stengs, I. (2009). Spontaneous shrines. In C. D. Bryant \& L. Peck (Eds.), Encyclopedia of death and the human experience (pp. 892-895). http:// dx.doi.org/10.4135/9781412972031.n295

Watkins, N., Cole, F., \& Weidemann, S. (2010). The war memorial as healing environment: The psychological effect of the Vietnam Veterans Memorial on Vietnam War combat veterans' posttraumatic stress disorder symptoms. Environment and Behavior, 42, 351-375. http://dx.doi .org/10.1177/0013916510361873

Westgaard, H. (2006). "Like a trace": The spontaneous shrine as a cultural expression of grief. In J. Santino (Ed.), Spontaneous shrines and the public memorialization of death (pp. 147-175). http://dx.doi.org/10 .1007/978-1-137-12021-2_8

Whitton, S. (2016). The Winston Churchill Memorial Trust of Australia. Retrieved from https://www.churchilltrust.com.au/media/fellows/ Whitton_S_2015_Mmethods_of_planning_and_managing_disaster_ memorials.pdf

Whitton, S. (2017). Psychosocial guidelines for temporary memorial management. Retrieved from https://www.redcross.org.au/getmedia/ 9569a682-8867-438f-be1b-331b6e79a314/2017-Psychosocial-guidelinesfor-temporary-memorial-management.pdf.aspx

Yocom, M. R. (2006). "We'll watch out for Liza and the kids": Spontaneous memorials and personal response at the Pentagon, 2001. In J. Santino (Ed.), Spontaneous shrines and the public memorialization of death (pp. 57-97). http://dx.doi.org/10.1007/978-1-137-12021-2_5

Received August 15, 2019

Revision received January 17, 2020

Accepted February 4, 2020 